\title{
INFLUENCE OF THE TIME OF THE DAY AND CHRONOTYPE ON SPEED ABILITIES IN JUNIOR TEAM ICE HOCKEY PLAYERS
}

\author{
Rastislav Pal'ov ${ }^{1}$ \\ ${ }^{1}$ Department of Physical Education and Sports, Faculty of Arts, \\ Matej Bel University, Banská Bystrica, Slovak Republic
}

\section{SUMMARY}

The aim of the study was to compare the effect of time of day and chronotype on the speed abilities on the sample of junior ice hockey players $(n=20$; defenders $=8$, forwards $=12$; age $=17.05 \pm 1.34$ years) playing in a competitive year 2013/2014 of Slovak extraligue of juniors. The influence of time of day and chronotype was detected on indicators of speed abilities (speed acceleration of lower legs). The test of acceleration speed was test time measured during the day on the basis of circadian rhythms of players, at 9 o'clock in the morning and 17 o'clock in the afternoon after the warm-up of the players (spaces of ice stadium Banská Bystrica). The criterion of performance evaluation was the average test time. We used Wilcoxon Signed Ranks Test $(\alpha=.01)$ to determine the significance of differences between morning and afternoon performance. Study has result in a different level of morning and afternoon levels of speed abilities that has shown that afternoon performance was higher than the morning. At up to 17 players we observed a higher level of speed abilities in the afternoon, thereof in 7 players the difference was in the level of statistical significance. Only in 3 of players we observed a higher level of speed abilities in the morning. Post hoc analysis have showed better average afternoon time $(8.58 \pm .17 \mathrm{~s})$ than average morning time $(8.65 \pm .19 \mathrm{~s})$. We found statistically significant differences $p<.01$. Based on analysis of chronotype in the file, we found that $15(75 \%)$ players of research group consisted mostly balanced types, $3(15 \%)$ players were evening type and $2(10 \%)$ players morning type. The time of players has not showed a main effect of test time-of-day or chronotype $(F=.56, p=.46$; $F=.08, p=.92$ ). The interactions between the factors were not statistically significant (test time of the day x chronotype: $F=.03, p=.97$ ). Evaluating the level of speed abilities of players in terms of chronotype and time of the day, we concluded that chronotype and time of the day has not main influence at the achieved level of speed abilities.i learning.

Key Words: acceleration speed, afternoon performance, morning performance.

\section{INTRODUCTION}

Ice hockey is a team sport, which is significantly affected by the performance of individual players. Physiological demands on the individual are different in terms of players' positions. For example, requirements for performance of forward and defender are larger than the goalkeeper. A number of factors affect performance of player, and one of them are timeconditioned biological changes. Players' performance changes throughout the day in response to the change of the physiological systems of the organism. Zeman
(2001) argues that circadian rhythms are the universal phenomenon of adaptation to all levels of the organization of living matter. These endogenous biological rhythms have evolved as an adaptation to cyclical changes in the environment indicated by the rotation of the Earth around its own axis.

There are various studies showing the modulation of circadian rhythmicity in sport performance. Among the possibilities for evaluating the influence of biological rhythms most often the studies are focused on the time of the day effect on the sport performance. Štulajter (2007) argues that biorhythmically favorable 
to the training process and for the given of performance in individual performance, especially in terms of speed and acceleration, are early mid-morning, meaning the beginnings inserted before $9.00 \mathrm{AM}$, when the curve of energy release has ascending character with the culmination point around 9.00 AM. The influence of circadian rhythms on the performance changes in speed-strength abilities during the day at the ski jumper aroused the attention of Schlank and Pupiš (2007). Based on the research results they concluded that the player has reached the highest performance during the day at noon. This is confirmed by Paugschová, Jančoková, and Šulej (2009), who have dealt with biorhythmical changes in the development of power and speed abilities of soldiers. They concluded that the best performance of subjects was recorded in the afternoon at 16 o'clock and some of the best performances recorded at 18 o'clock. Pivovarniček, Bunc, Malý, Kollár, and Jančoková(2013) and Pivovarniček, Sližik, Kollár, Mojžǐš, and Jančoková (2012) did not detect or find any significant differences $(p>.05)$ between morning and evening performance of speed indicators of the young football players. Rošková and Demjan (2011) examined psychological and physical performance of female university students $(n=24)$ at 8.00 and at $11.00 \mathrm{AM}$ and at 2.00 and at $5.00 \mathrm{PM}$. The maximal performance was detected at 5.00 PM. Paugschová and Ondráček (2011) made research about diurnal rhythm of speed and strength preconditions of high school female students $(n=10)$ at 9.00 and $12.00 \mathrm{AM}$ and at 3.00 and 6.00 PM. The strength preconditions showed maximal levels at $9.00 \mathrm{AM}$ and at 6.00 PM. The highest level of speed preconditions was achieved at 12.00 AM.

In the implementation of our experiment must be considered in addition to circadian rhythms also effect of an individual chronotype. Ronneberg (2012) describes chronotype as a genetic component or everyday human behavior, in which it comes to phasic changes in human life, which vary in the length of sleep, melatonin levels, body temperature and other circadian oscillating of physiological parameters. We know the different methods which classify individuals according to their chronotype, among them, one developed by Horne and Ostberg (1976). Based on the results of the questionnaire, subjects are divided into five different categories: extreme morning type, moderate morning type, intermediate type, moderate afternoon type, and extreme afternoon type. Barbosa and Albuquerque (2008), Kim, Dueker, Hasher, and Goldstein (2002), and May and Hasher (1998) have suggested that the chronotype of a sub- ject may change over the course of life and studies indicate that in childhood (between 8 and 12 years) there is a tendency towards being a morning type, whereas in adolescence and in the early adult phase, there is a tendency towards being an afternoon type, returning to the morning type tendency in old age. Researches made by Vančová, Jančoková, Palovičová, and Pivovarniček (2013), and by Vančová and Palovičová (2013) showed that more than $77.4 \%$ of female university students tend to be neither chronotype. It is because female university students have no strict and fixed daily regime and have no time stereotype because of timetable - variability of lectures and seminars, what confirms synchronization of chronotype by external requests and impulses.

Brown, Neft, and LaJambe (2008) has researched sportsmen divided into three groups - morning types, evening types and balanced (neutral) types and then examined performance of sportsmen in the early morning hours at 5.00 to $7.00 \mathrm{AM}$ and late afternoon from 4.30 to 6.00 PM. The authors did not detected significantly different performance based on typology (chronotype) of sportsmen in terms of time of day and stated that these results may be affected by training time stereotypes of sportsmen.

\section{METHODS}

The research sample included 20 junior team players HC’05 Banská Bystrica aged 16-19 years (average age decimal of players is $17.05 \pm 1.34$ years).

The research was conducted during the preparation period on ice under year training cycle 2013/2014. Diagnostics of level speed abilities took place from $07 / 25 / 2013$ to $07 / 31 / 2013$ at the premises of ice stadium in Banská Bystrica. Distribution, completion and collection of questionnaires took place in Thursday, $07 / 25 / 20137.30$ to $8.00 \mathrm{PM}$ at the premises of ice rink before the workout. The players were divided into three groups based on the score achieved in Horne and Ostberg (1976), (Slovak version of the questionnaire). Moderate morning types were classified as morning types and moderate evening types as evening types. Three players were identified as evening type (score $38.67 \pm 3.54$ ), two as morning type (score $64.50 \pm 6.36$ ) and fifteen as balanced type (score 49.53 \pm 4.67 .

We investigated the level of speed abilities, namely the acceleration speed of skating during the preparatory period on ice in skating forward at $40 \mathrm{~m}$ with changes of direction (Figure 1).

The test time of players was measured during the day on the basis of circadian rhythms of players, at 


\section{FIGURE 1}

Scheme of the test of skating forward 40 meters, with changes of direction

(Source: wmw. hockeyslovakia.sk).

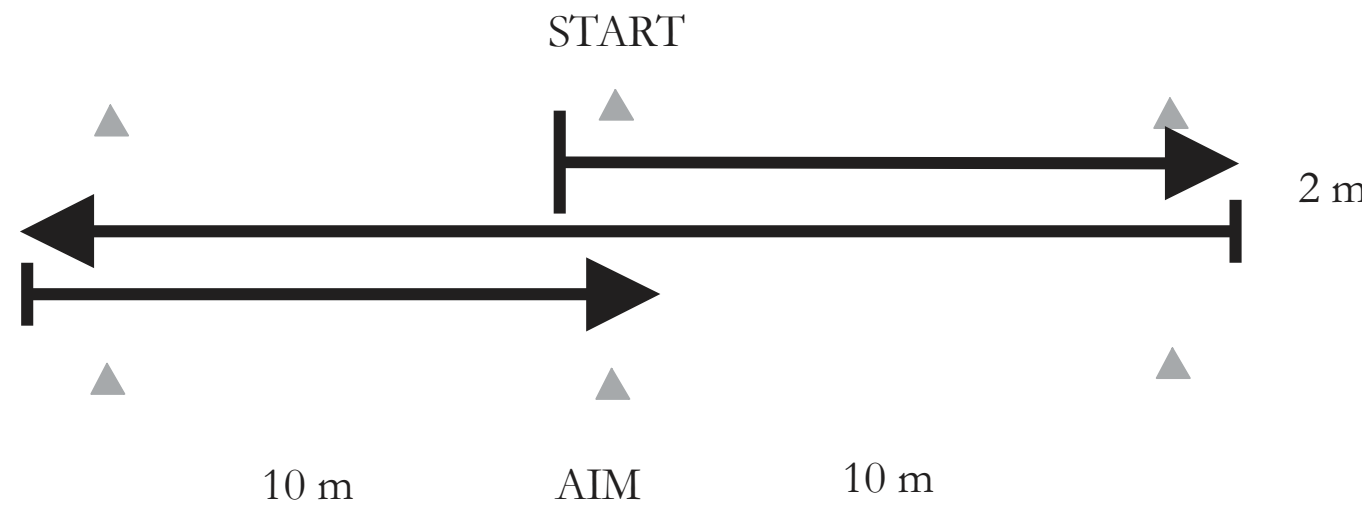

9 o'clock in the morning and 17 o'clock in the after- speed abilities. In the study we have determined imnoon after the warm-up of players.

The time of players in the test of skating forward 40 meters with changes of direction was used as dependent variable. Time of player was measured by using a hand-held stopwatch and we compiled the exact track, which tested player had to complete. As performance criteria, we used the time in seconds. We realized the test three times in order to eliminate the effect of improving the performance by impact of experience gained during the implementation of the tests (Zemková, 2008) and in the evaluation we better result. For the statistical evaluation of the sample results, we used the nonparametric Wilcoxon test to determine the significance of differences between the morning and afternoon performance of the sample. We used Two-way ANOVA: chronotype and time of the day to prove effect of the factors on portance on standardly used $\alpha$ - level (alpha) $=.01$. Statistical analysis was realized with software Statistica 12.

\section{RESULTS}

Post hoc analysis have showed better average afternoon time $(8.58 \pm .17 \mathrm{~s})$ than average morning time $(8.65 \pm .19 \mathrm{~s})$ (Figure 2). We found statistically significant differences $p<.01$ (Table 1).

Our results are similar to those of several authors, for example Atkinson, Todd, Reilly, and Waterhouse (2005), Reilly et al. (2007), who concluded that the afternoon performance was higher than the morning.

The time of players has not showed a main effect of test time-of-day or chronotype $(F=.56, p=.46$; $F=.08, p=.92)$. The interactions between the factors

FIGURE 2

Average morning and afternoon time of the players.

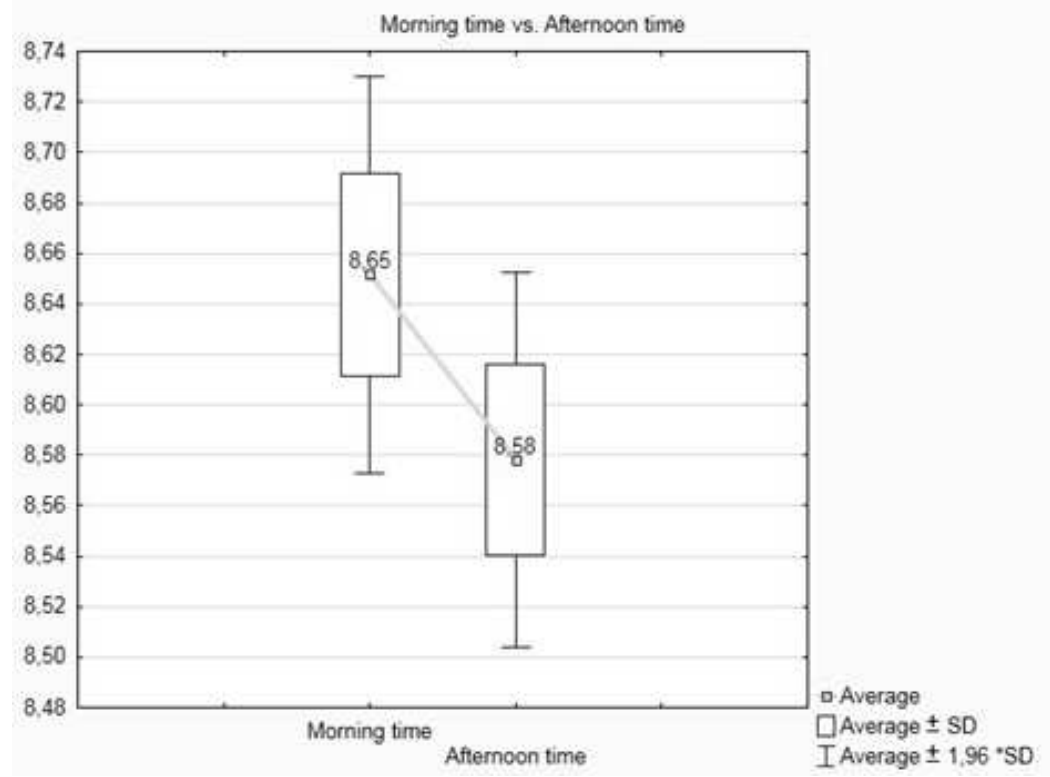




\section{TABLE 1}

The comparison of morning and afternoon time in seconds (s).

\begin{tabular}{lcccccc}
\hline & M & \multicolumn{2}{c}{ SD } & \multicolumn{2}{c}{ Me } & \multicolumn{2}{c}{ Min } & \multicolumn{2}{c}{ Max } & \multicolumn{2}{c}{$\mathbf{R}_{\text {max }-\min }$} \\
\hline Morning time (s) & 8.65 & .18 & 8.63 & 8.32 & 9.07 & .74 \\
\hline Afternoon time (s) & 8.58 & .17 & 8.58 & 8.24 & 8.98 & .75 \\
\hline
\end{tabular}

Legend/Legenda: Morning time - Vrijeme postignuto ujutro; Afternoon time . Vrijeme postignuto poslijepodne; M - Mean (Aritmetička sredina); SD - Standard deviation (Standardna devijacija); Me - Median (Medijana); Min - Minimum (Minimum); Max Maximum (Maksimum); $\mathbf{R}_{\max -\min }$ - Variation margin (Varijaciona margina).

\section{FIGURE 3}

Influence of test time of the day and chronotype on performance.

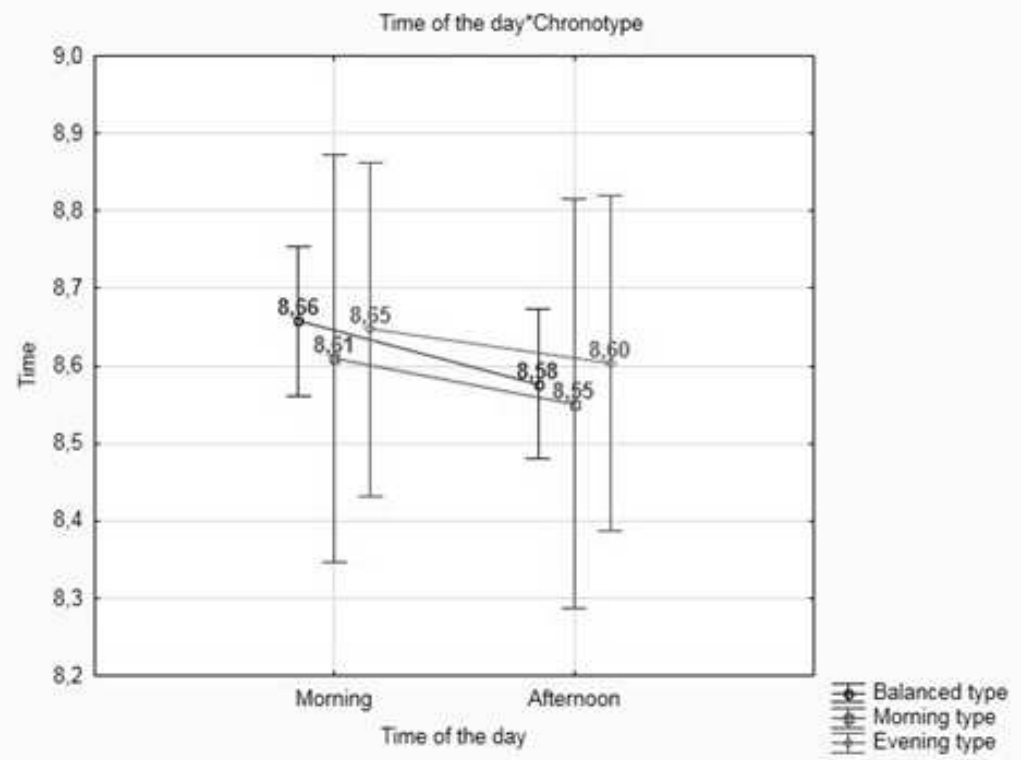

were not statistically significant (test time of the day $\mathrm{x}$ chronotype $(F=.03 ; p=.97)$ (Figure 3).

\section{DISCUSSION}

The main reason of this study was to find if the time of the day and chronotype affect the level of speed abilities. We first examined the level of speed abilities in terms of time. We found that level of speed abilities was statistically significantly higher in the afternoon than in the morning that demonstrated influence of circadian rhythms on the performance changes. The same findings were published by Schlank and Pupiš (2007) in speed-strength abilities during the day at ski jumper. Based on the research results we concluded that the player has reached the highest performance during the day at noon. Gereková (2009) dealt with the changes in performance, speed and strength abilities biathlete during the day on the basis of circadian rhythms and concluded that the best time for the development of speed skills in volunteer was about 18 o'clock in the evening. A significant drop in performance occurred at 21.00 o'clock. This is confirmed by Paugschová ez al. (2009), who have dealt with biorhythmically changes in the development of power and speed abilities of soldiers. They concluded that the best performance of subjects was recorded in the afternoon.

In the implementation of our experiment must be considered in addition to circadian rhythms also effect of an individual chronotype. Venugopal, Gupta, and Patel (2010) conducted a study to monitor the effect of time of day on the various parameters such as body temperature (body temperature fluctuations closely correspond to the performance fluctuations) and concluded that the peak body temperature was recorded in the afternoon. We agree with Jančoková et al. (2011) that the results of previously conducted studies show a higher performance achieved in the late afternoon or evening, around the time of 4.00 to $8.00 \mathrm{PM}$, than in the morning from 07.00 to 
10.00 AM. Singh and Subramanian (2012) conducted research on a sample of 19 athletes of the Indian national team, and concluded that their performance was highest during the evening meeting at the time of 4.00 to 5.00 PM.

Secondly, we investigated the effect of chronotype on level of speed abilities. The players of this study were young, who tend to be balanced in terms of chronotype. For this reason, we believe that the chronotype did not affect the level of speed abilities of the players. The time of players has not showed a main effect of chronotype. The similar study realized Barbosa and Albuquerque (2008) and concluded that the subjects of their study were mostly young, a population with a greater tendency for being afternoon types. In this case, it could be suggested that the better performance of individuals who trained in the afternoon was a result of a synchronic effect and not related to training time-of-day training. Lastella et al. (2010) found that triathletes at the elite level tend to show either morning or neither preference. There were no E-types within this sample of elite triathletes. This finding supports the notion that E-types do not select sports which require early morning training.

The results from the present study revealed that junior ice hockey players performance is higher at noon and the test time of the day and chronotype did not mainly influence it. We should expand our study on effect of training time on level of speed abilities. These findings could help us to improve effect of training on sport performance. Despite of recognized results about chronotype, we agree with Vančová and Pivovarniček (2013) that a scientific challenge is a question of confirmation or rejection of the detection that human's chronotype influences the effectivity in sport and work activity not only in sport but also in general everyday life during the day in term of diurnal and circadian rhythms.

\section{CONCLUSION}

The main finding of this study is that there is no main influence of time of the day and chronotype on average time of players. We recorded the difference between morning and afternoon level of speed abilities in favor of the afternoon. The observed difference was significant $(\phi<.01)$. Our results are similar to Barbosa and Albuquerque (2008) who concluded that there is no main effect of test time and chronotype on LTM performance. They found main effect of training time of the day and that there is no interaction between LTM test time-of-day and chronotype, indicating the absence of a synchronic effect.
In terms of representativeness of the research it would be needed to carry out research on a larger sample of players, over a longer period of time and not just in the specific group of sportsmen. Many authors who have dealt with similar theme focused on exploring of body temperature, therefore we consider necessary to focus on exploring this indicator in relation to circadian rhythms.

\section{ACKNOWLEDGEMENTS}

The study is a part of the research project VEGA no. 1/0757/12 Reactive and adaptation indicators of changes of physical and psychological sportsmen abilities in sequence with biorhythms of various period's length.

\section{REFERENCES}

Atkinson, G., Todd, C., Reilly, T., \& Waterhouse, J. (2005). Diurnal variation in cycling performance: Influence of warm-up. Journal of sport sciences, 23(3), 321-329. doi: 10.1080/02640410410001729919; PMid: 15966350

Barbosa, F. F., \& Albuquerque, F. S. (2008). Effect of the time-of-day of training on explicit memory. Brazilian journal of medical and biological research, 41(6), 477-481. doi: 10.1590/S0100879X2008005000023; PMid: 18560671

Brown, F. M., Neft, E. E., \& LaJambe, C. M. (2008). Collegiate rowing crew performance varies by morningness-eveningness. Journal of strength and conditioning research / National Strength \& Conditioning Association, 22(6), 1894-1900. doi: 10.1519/JSC.0b013e318187534c; PMid: 18978619

Gereková, J. (2009). Biorytmické zmeny v rozvoji vybraných pohybových schopností a ich vplyv na výkonnost' v biatlone (Diplomová práca) [Biorhytmical changes in development of selected motor skills and their impact on performance in biathlon]. Unpublised doctoral thesis. Banská Bystrica, SK: FHV UMB.

Horne, J.A., \& Ostberg, O. (1976). A selfassessment questionnaire to determine morningness-eveningness in human circadian rhythms. Chronobiology international. 4(2), 97110.

Jančoková, L', Bendíková, E., Kalinková, M., Matejovičová, B., Palovičová, J., Paugschová, B., Pivovarniček, P., \& Mojžišs, M. (2011). Chronobiológia a výkonnost' $v$ športe 
[Chronobiology and sports performance]. Matej Bel University, FHV.

Kim, S., Dueker, G. L, Hasher, L., \& Goldstein, D. (2002). Children's time of day preference: age, gender and ethnic differences. Personality and Individual Differences, 33(7), 1083-1090. doi: 10.1016/S0191-8869(01)00214-8

Lastella, M., Roach, G. D., Hurem, D. C, \& Sargent, C. (2010). Does chronotype affect elite athletes' capacity to cope with the training demands of triathlon? In C. Sargent, D. Darwent, and G. D. Roach (Eds), Living in a 24/ 7 world: The impact of circadian disruption on sleep, work and health (pp. 2528). Adelaide, Australia: Australasian Chronobiology Society.

May, C. P., \& Hasher, L. (1998). Synchrony effects in inhibitory control over thought and action. Journal of experimental psychology. Human perception and performance, 24(2), 363-379. doi: 10.1037/0096-1523.24.2.363; PMid: 9554091

Paugschová, B., Jančoková, L., \& Šulej, P. (2009). Biorytmické zmeny v rozvoji silových a rýchlostných schopností vojakov [Biorhythmical changes in development of strength and speed abilities of soldiers]. Exercitatio corpolis - motus salus, 1(1), 70-79.

Paugschová, B., \& Ondráček, J. (2011). Denné zmeny rýchlostných a silových schopností študentiek 1. ročníka gymnázia [Daily changes of speed and strength abilities of female students of the first year at grammar school]. In Rošková, M. (Ed.), Acta Facultatis Humanisticae Universitatis Matthiae Belii (pp. 113-128). Banská Bystrica, Slovakia: FHV UMB.

Pivovarniček, P., Bunc, V., Malý, T., Kollár, R., \& Jančoková, L. (2013). Diurnálne oscilácie bežeckej rýchlosti mladých futbalistov [Diurnal oscillations of the running speed of young soccer players]. Czech Kinanthropologhy, 17(1), 8592.

Pivovarniček, P., Sližik, M., Kollár, R., Mojžǐš, M. \& Jančoková, L. (2012). Diurnálne oscilácie frekvenčnej rýchlosti mladých futbalistov [Diurnal oscillations of the tapping frequency of young soccer players]. Exercitatio corporis motus - salus $=$ Slovak journal of sports sciences, 4(2), 36-44.

Reilly, T., Atkinson, G., Edwards, B., Waterhouse, J., Farrelly, K., \& Fairhurst, E. (2007) Diurnal variation in temperature, mental and physical performance, and tasks specifically related to football (soccer). Chronobiology international, 24(3),
507-519. doi: 10.1080/07420520701420709; PMid: 17612948

Ronneberg, T. (2012). What is chronotype? Sleep and Biological Rhythms, 10(2), 75-76. doi: 10.1111/j.1479-8425.2012.00541.x

Rošková, M., \& Demjan, M. (2011). Zmeny v úrovni psychickej a pohybovej výkonnosti $\mathrm{v}$ priebehu denného rytmu [Level's changes in psychological and physical performance in daily rhythm process]. In M. Rošková (Ed.), Acta Facultatis Humanisticae Universitatis Matthiae Belii Neosoliensis (pp. 139-149). Banská Bystrica, Slovakia: FHV UMB.

Schlank, P., \& Pupiš, M. (2007). Biorytmické zmeny rýchlostno-silových schopností skokana na lyžiach [Biorhythmical changes of a ski jumper's speed-strength abilities]. In n.n. (Ed.), Kvalita zivota (pp. 179-185). Ústí nad Labem, Czech Republic: Univerzita J. E. Purkyně.

Singh, P. K., \& Subramanian, R. (2012). Circadian Variation of Selected Motor Performance. International Journal of Health, Sports and Physical Education, 1(1), 16-19.

Štulajter, I. (2007). Vplyvy biorytmov na vybrané pohybové schopnosti vo futbale Impacts of biothythms on selected motor skills in soccer]. Banská Bystrica, Slovakia: FHV UMB.

Vančová, D., Jančoková, L., Palovičová, J., \& Pivovarniček, P. (2013). Identifikácia chronotypov vysokoškolských študentiek IIdentification of chronotypes of university students]. Studia sportiva, 7(2), 79-84.

Vančová, D., \& Palovičová, J. (2013). Analýza chronotypu študentiek FHV a FPV UMB v Banskej Bystrici [Chronotype's analysis of FHV and FPV university students attending Matej Bel university in Banská Bystrica]. In K. Baisová and M. Kružliak (Eds.), Telesná výchova a šport (pp. 307-323). Zvolen, Slovakia: TU.

Vančová, D., \& Pivovarniček, P. (2013). Chronotyp a psychické charakteristiky [Chronotype and psychological characteristics]. In L'. Jančoková, E. Bendíková, and P. Pivovarniček (Eds), Chronobiológia od teórie k športovej praxi (pp. 172197.) Banská Bystrica, Sloavkia: UMB Belianum.

Venugopal, R., Gupta, O., \& Patel, H. (2010). Temporal Pattern of Circadian Rhythm in Sportsmen. Journal of Exercise Science and Physiotherapy, 6(1), 1-6.

Zeman, M. (2001). Základy chronobiológie [Basics of the chronobiology]. Bratislava, Slovakia: UK. 
Zemková, E. (2008). Diagnostika koordinačných schopnosti [Diagnostics of coordination abilities].
Bratislava, Slovakia: FTVŠ UK. PMCid:

PMC2538769

Received: October 17, 2014

Revision received: November 30, 2014

Accepted: December 21, 2014

Correspondence to: Rastislav Pal'ov, MSc.

Faculty of Arts

Matej Bel University

Tajovského 40

97401 Banská Bystrica

Slovakia

Phone: 00421484467524

E-mail: rastislav.palov@umb.sk 